\title{
Erratum to: Visualization of geotechnical data by means of geographic information system: a case study in Eskisehir city (NW Turkey)
}

\author{
Ahmet Orhan · Hasan Tosun
}

Published online: 23 July 2010

(C) Springer-Verlag 2010

\section{Erratum to: Environ Earth Sci}

DOI 10.1007/s12665-009-0357-1

The original version of this article unfortunately contained a mistake. The address of Hasan Tosun was incorrect. The correct address is given below:

Agricultural Faculty, Eskisehir Osmangazi University, Eskisehir, Turkey

The online version of the original article can be found under doi:10.1007/s12665-009-0357-1.

\footnotetext{
A. Orhan $(\bowtie)$

Geological Engineering Department,

Engineering Architecture Faculty,

Eskisehir Osmangazi University,

Eskisehir, Turkey

e-mail: aorhan@ogu.edu.tr

H. Tosun

Agricultural Faculty, Eskisehir Osmangazi University,

Eskisehir, Turkey
} 